\title{
Okonomiens geologi - oliecivilisationens opsving og nedtur
}

Af Klaus Illum, civilingeniør, lic. techn., ECO Consult

Det at tage bilen på arbejde eller flyve til feriedestinationen er en naturlig selvfølge for mange mennesker. Hvad, de færreste tænker på, er, at olien skal komme et sted fra. Analyser viser, at det fortsat stigende forbrug i løbet af nogle få år vil kunne afstedkomme en for verdensøkonomien fatal oliekrise.

"The evidence presented in this review shows that forecasts made by governmental and international institutions differ markedly from the results of analyses made by individual, independent researchers and some analysts representing the oil industry. The oil industry's analysts point to ever greater costs of matching growing demand with supply from an aging resource base.

Depending mainly on developments in the Middle East and the development of the world economy in the coming years, production may peak within one or two decades. It is a question of geology, technology, economy, and the policies conducted by various nations. The trouble is that no realistic technological, economic and political strategies for the warding off of the impacts of a decline in conventional oil supply are in sight".

Fra Teknologirådets og Ingeniørforeningens udredning Oil-based Technology and

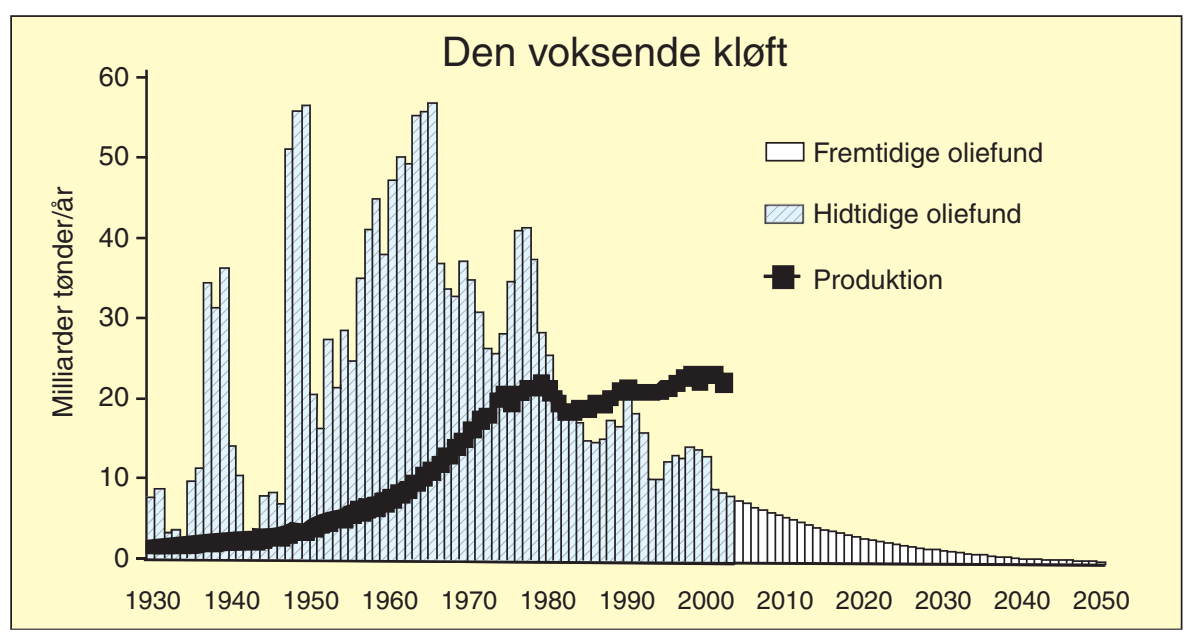

De fleste oliereserver blev fundet før 1980. Derefter har det årlige forbrug varet større end de årlige fund. (Grafik: UVH modificeret efter Colin. J. Campbell, ASPO Newsletters, www.asponews.org)

Economy - Prospects for the Future (april 2004, www.tekno.dk).

Forbruget vokser - reserverne udtømmes Hvis ovenstående var skrevet i dag - fem måneder senere - ville der ikke have stået "production may peak within one or two decades", men "production will peak within one or two decades", med den tilføjelse at produktionen næppe vil kunne dække den stigende efterspørgsel efter 2010, med mindre verdensøkonomien forinden løber ind $\mathrm{i}$ en recession, der kraftigt dæmper olieefterspørgslen.

Analyser fremlagt af oliegeologen Colin J. Campbell viser, at produktionen vil toppe ved 30 milliarder tønder om året. Hvis forbruget i de kommende år steg med 1,2\% om året, ville toppen nås i 2010 . Stigningen er imidlertid nu nået op på mere end 2,5 \% om året. Det betyder, at selv hvis det i henhold til mere optimistiske vurderinger antages, at produktionen kan nå op på 36 milliarder tønder om året, så nås toppen alligevel omkring 2010.

Husk nu på, at forbrugsstigningen, hvad enten den er 1,5 eller $2,5 \%$ om året, betyder, at bilfabrikkerne, flyfabrikkerne, skibsværfterne og de, der laver traktorer og landbrugsmaskiner, sender flere og flere olieforbrugende motorer i omløb. Der skal jo flere motorer til at forbruge mere olie. Og de kræver nye vejanlæg, lufthavne og havne. Dvs. at verdensøkonomien bliver mere og mere afhængig af olie -indtil denne vækst pludselig går i stå, fordi der ikke kan produceres olie nok til at holde alle disse motorer i gang i det omfang, den økonomiske vækst forudsætter. 


\section{Økonomisk recession}

At en vækst $\mathrm{i}$ olieproduktionen $=$ forbruget på $1,5-2,5 \%$ om året afløses af et fald på 1,5-2,5\% om året betyder, at der er nogle, der må køre og flyve mindre. Så længe markedet råder, kommer olieprisen således der op, hvor efterspørgslen er lig produktionskapaciteten. Nogle har så høje lønninger, at de har råd til at køre og flyve lige så meget, som de plejer, selvom en liter benzin koster $20 \mathrm{kr}$. Men de fleste kommer til betale mere, end de plejer, selvom de nedbringer deres forbrug. Samtidigt stiger varepriserne, når industrier og landbrug skal overføre hundreder af milliarder af dollars til de private olieselskabers og OPECs nationale selskabers bankkonti. Det fører til økonomisk recession; dyrere fødevarer; flyselskaber, rejsebureauer og bilfabrikker går konkurs; tumulter på kapitalmarkederne; fald i dollar-kursen (sålænge råolie handles i dollar); arbejdsløshed; fald i olieefterspørgslen; prisfald på olie. Igen lidt økonomisk opsving; olieefterspørgslen vokser; olieprisen op igen. Op og ned, men mest ned, fordi olieforbruget nødvendigvis må følge den dalende produktion. Og nedgangen bliver relativt større for de mindre bemidlede og de fattige her på Jorden.

De tilbageværende bilfabrikker får travlt med at lave mindre biler, der kan køre længere på literen, men mange vil ikke have råd til at udskifte deres biler. Og de hundreder af millioner familier, der bor i olieopvarmede huse, må sætte stuetemperaturen ned, hvis de ikke kan finde andre måder at varme op på.

Det er sådanne bratte omskiftelser, vi kommer til at opleve, når det vigtigste ressourcegrundlag for de livsformer og produktionsforhold, der er opbygget i de sidste 50 år, begynder at smuldre, så der bremses for væksten i den oliebaserede økonomi i alle industrisamfundene. Samtidigt er der blevet en milliard flere mennesker på Jorden, som alle stræber efter at komme til at leve, sådan som vi endnu gør.

Kun få økonomer beskæftiger sig med disse fremtidsudsigter. Fordi opbremsning af den økonomiske vækst på grund af ressourcebegrænsninger ikke kan håndteres af deres teoretiske, makroøkonomiske modeller. Og ingen politikere har nogen anelse om, hvad de skal stille op - andet end nogle flere vindmøller og nogle brintluftkasteller, som man forestiller sig vil kunne erstatte 30 milliarder tønder olie om året.

\section{Menneskets irrationelle adfærd}

Måske kan mennesker selv efter, at en faldende olieproduktion har skabt økonomisk recession og globale omvæltninger, udvikle nye teknologier, der kan frembringe de for samfundets funktioner nødvendige drivkræfter. Måske ikke. Under alle omstændigheder vil det være ulige meget sværere, end hvis udviklingen af nye energisystemer planlægges og iværksættes, før oliemangel sætter ind med økonomisk recession og tumult. Men tiden er måske forpasset.

Hver for sig er mennesker intelligente, og

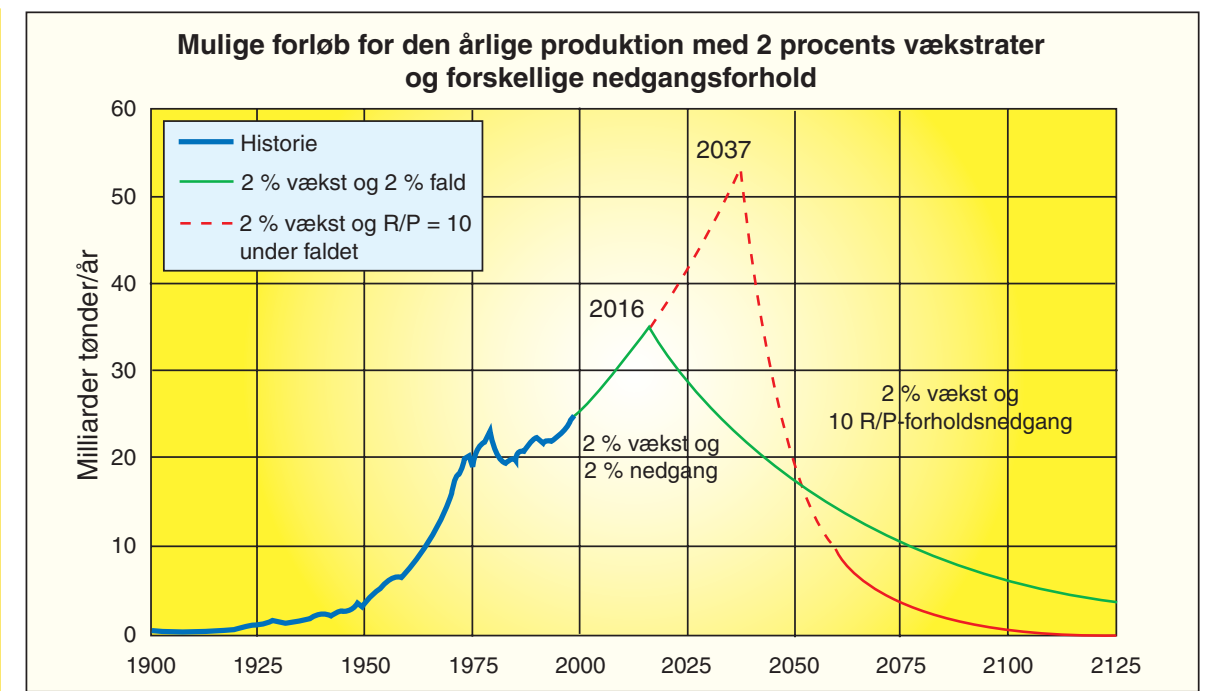

Jo langere vaksten fortscetter, des kraftigere bliver faldet, når toppen nås. Figuren viser to teoretiske forløb. I det ene tilfalde antages produktionen at falde med $2 \%$ om året. I det andet tilfcelde antages forholdet mellem tilbagevarende reserver og årlig produktion ( $R / P$-forholdet) at vare konstant lig 10 under faldet. Arealet under den ene kurve fra 1900 - 2125 er det samme som arealet under den anden kurve nemlig 3.000 mia. tønder, som er middelvardien af de af US Geological Survey's sandsynlighedsteoretiske vurderinger af de oprindelige samlede tilgangelige oliereserver - en mongde, som ligger ca. $25 \%$ over de fleste andre vurderinger. (Grafik: UVH modificeret efter US Department of Energy, Energy Information Administration (EIA), 2000) nogle er geniale og fremsynede. Men kollektivt opfører vi os irrationelt. Hvad angår vores forbrug af vores mest dyrebare ressource - olie - opfører vi os som dyr, der lever i nuet. For eksempel som to rotter, der bliver spærret inde i en lade med en sæk korn. De vil leve fedt af kornet og formere sig til hundreder - indtil den sidste kerne er ædt. Vi ved, at olieressourcerne er endelige, og at enden er i sigte, og vi ved, at vi ikke uden yderligere at accelerere klimaændringerne kan producere olie af tjæresand, olieskifer og kul. Alligevel driver det økonomiske vækstsystem, der bestemmer vilkårene for vores dagligdag, os til en adfærd, der minder om rotternes-eller lemmingernes.

Vi bilder os ind - eller bliver bildt ind - at væksten kan fortsætte. Det kan vi jo se, når vi ser tilbage på de sidste to århundreder: vedvarende accelereret økonomisk vækst. Og allerede i årene efter, at de første oliefelter var blevet åbnet i Pennsylvania i slutningen af det 19. årh., kom de første forudsigelser om olieressourcernes snarlige udtømning. Men disse forudsigelser er blevet gjort til skamme igen og igen op gennem det 20. årh. Pessimister og dommedagsprofeter mer", men den kom jo ikke. Og skulle den komme, skal vi nok få drevet den væk med nye teknologier. Lomborg gentager den velkendte sentens: "Stenalderen endte ikke på grund af mangel på sten. Og oliealderen vil ikke ende på grund af mangel på olie.”. Historien viser, at væksten kan fortsætte og ikke lader sig standse. har med jævne mellemrum råbt "ulven kom-

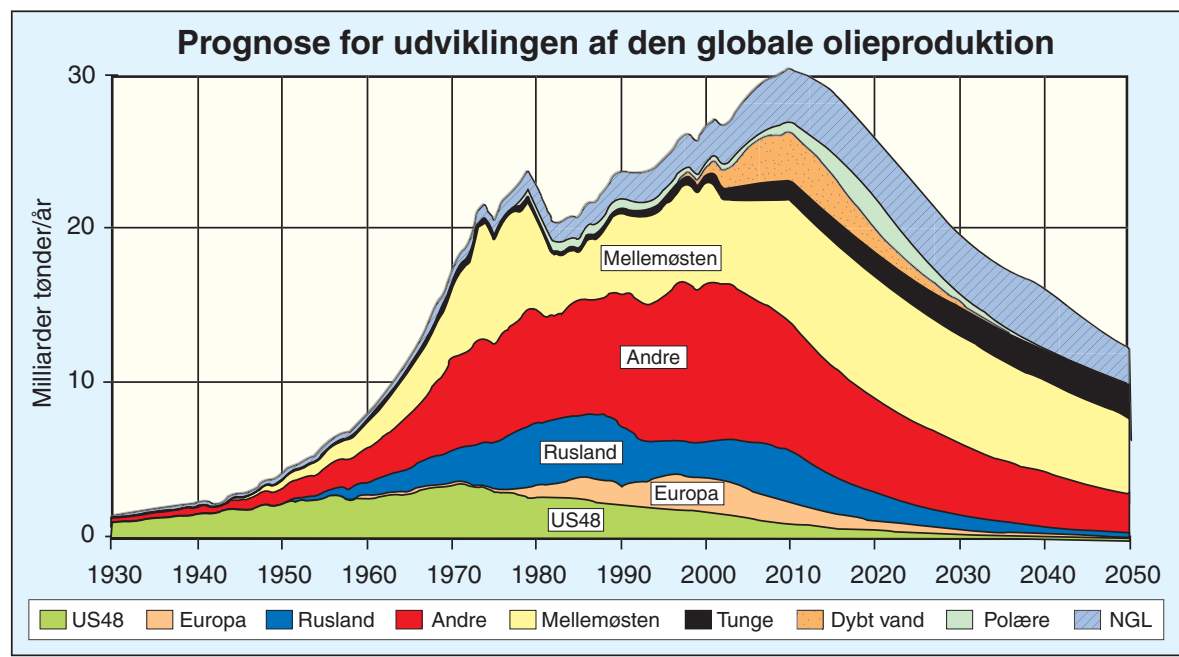

Reserveopgørelser og produktionsdata er behwftet med stor usikkerhed. Denne figur er baseret på en opgørelse af de globale reserver til 1.900 mia. tønder, hvoraf ca. 900 mia. tønder allerede er forbrugt. En forøgelse af de opgjorte reserver og af de fremover forventede fund med $20 \%$ udskyder kun det tidspunkt, hvor produktionen topper med 4 - 6 år afhongigt af forbrugsstigningen; NGL: Natural Gas Liquids, d.e. kondensater fra gasudvinding og raffinering. (Grafik: UVH modificeret efter Colin J. Campbell, 2003) 


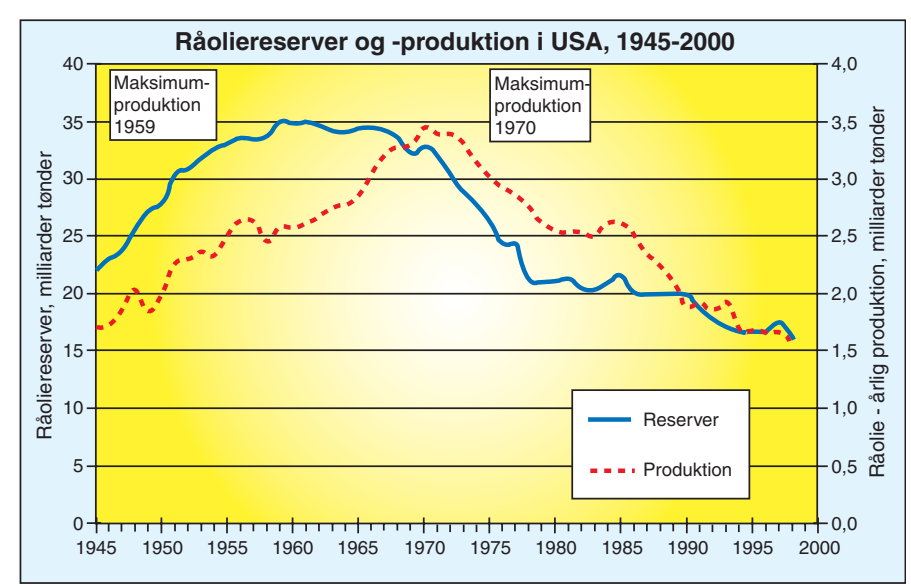

I USA (uden Alaska) toppede reservetilveeksten i 1959. 11 år efter, i 1970 toppede produktionen. Derefter er den faldet med mere end $50 \%$. En tilsvarende udvikling kan forventes i verden som helhed. (Grafik: UVH modificeret efter US Department of Energy, Energy Information Administration (EIA), 2000)

Nej, det gør den ikke. For eksponentiel vækst har sin egen historie. De fleste kender det regnestykke, der tydeliggør den eksponentielle væksts egenart: Regnestykket om vandhyacinten, der i løbet af tre dage bliver til to. I en stor sø har sådanne vandhyacinter i løbet af 10 år bredt sig så de dækker $1 / 10$ af søens overflade. Hvor mange dage går der nu, før hele overfladen er dækket? 10 dage! I dette eksempel er tidsskalaen dage. Når vi ændrer fordoblingstiden fra tre dage til 30 år - svarende til en økonomisk vækst på 2,3\% om året - og fx antager, at $20 \%$ af Jordens $ø$ kologiske bæreevne var udnyttet i 1960, så når vi 60 \% i 2005 og 100 \% i 2030. Derfor er udviklingens tidsmålestok ikke længere århundreder, men årtier.

I det punkt på vækstkurven, vi nu befinder os i, kan udviklingen ikke fremskrives ud fra historiske vækstdata. Fordi oliereserverne ikke som olieforbruget vokser eksponentielt. Hovedparten af de kendte reserver blev fundet før 1980. Fordi udviklingen i den globale olieproduktion bliver som udviklingen i USA, hvor fortsat efterforskning og brug af moderne udvindingsteknologier ikke har kunnet standse den produktionsnedgang, som satte ind i 1970. Og fordi fortsat vækst i forbruget af fossile brændsler medfører klimaændringer og således ikke er bæredygtig dvs. fører til sammenbrud.

\section{Enestående udvikling på retur}

Vi må erkende, at vi befinder os i et singulært punkt i menneskehedens udviklingshistorie. I et punkt, hvorfra der ikke længere er kontinuitet i udviklingen af samfundets teknologiske infrastrukturer. Tidligere har udviklingen gjort tingene lettere. Fra håndkraft til hestekraft; fra årer til sejl; fra hestekraft og sejl til kulfyrede dampmaskiner; fra dampmaskiner til oliemotorer, der har gjort det muligt at bevæge sig til lands, til vands og i luften med førhen usete hastigheder og at pløje 100 ha på et par dage med én mand på en $300 \mathrm{HK}$ traktor. Men her stopper denne fremadskridende udvikling til det sta-

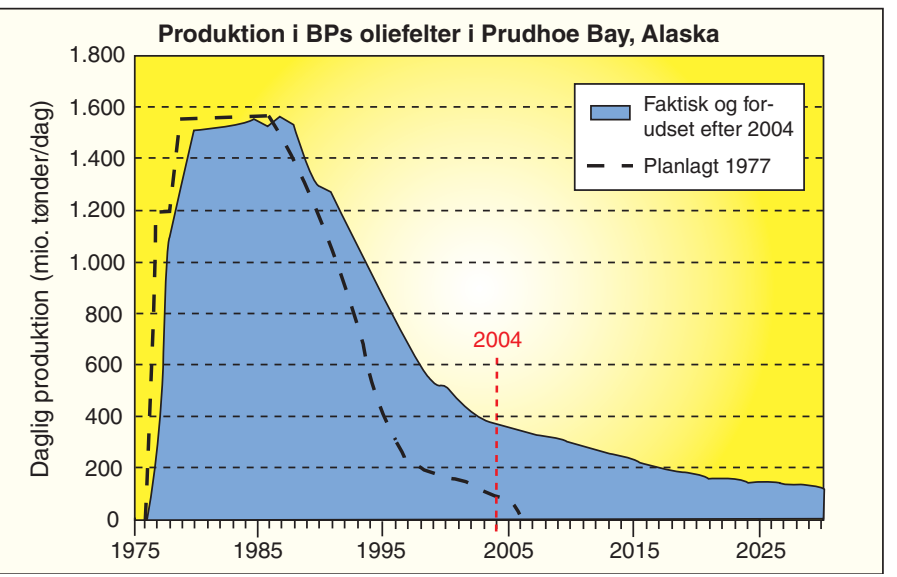

Produktion i BPs oliefelter i Prudhoe Bay, Alaska. Ved en kraftig og dyr indsats med nye udvindingsteknikker er det lykkedes at forøge udvindingsgraden af den olie, der findes i felterne, fra $45 \%$ til $60 \%$, og således at bremse produktionsfaldet. Men sådanne dyre udvindsteknikker bringes først i anvendelse, når olien i langere tid "kommer op af sig selv", dvs. når produktionen er toppet. (Grafik: UVH modificeret efter Francis Harper, tidligere direktør $i$ BP)

digt lettere. Intet er så let at udvinde, transportere og lagre som olie. Intet andet brændstof har så stor energitæthed. Nu bliver alt meget vanskeligere.

Vi befinder os i en helt enestående situation, der har sine helt unikke forudsætninger i Jordens geofysiske historie. I to korte epoker for 90 og 145 mio. år siden skete der en ekstrem opvarmning af Jordens atmosfære. Opvarmningen afstedkom en voldsom algevækst $i$ havene, og i nogle havområder med iltfattigt bundvand sank de døde alger til bunds og blev aflejrede sammen med sand og ler. Siden blev disse aflejringer dækket af andre bjergarter. På steder, hvor de således kom ned i dybder mellem 2.000 og 5.500 meter, blev det organiske materiale i tidens løb omdannet til olie. I større dybder blev det omdannet til naturgas. Det meste af olien og gassen undslap gennem sprækker og porøse bjergarter til overfladen, men en del blev fanget $i$ lommer under uigennemtrængelige bjergarter. Disse lommer er de olie- og naturgasfelter, vi nu er i gang med at tømme.

\section{Civilisationens endeligt?}

Hvis disse særegne biologiske og geologiske processer ikke havde udfoldet sig i en fjern fortid, eller hvis olien og gassen ikke var blevet fundet - eller kun en mindre del var blevet fundet $i$ de sidste 100 år - havde vores verden set anderledes ud i dag. Vi ved, hvordan mennesker i de sidste årtusinders civilisationer under de forskellige livsvilkår, denne klode har budt på, har skabt de redskaber og teknologier, hvormed de udviklede de mangfoldige, forskelligartede kulturers samfundsordener, økonomier, verdensopfattelser og kunstformer. Men få erkender til fulde, at vores civilisations økonomi, verdensopfattelse og kunstformer, helt og aldeles er betinget af de unikke livsvilkår, olien og olie-teknologierne i en kort periode har frembragt. At vi lever i en civilisation, som ikke kun er historisk enestående, men også i enhver henseende, både kvantitativt og kvalitativt, er usammenlignelig med alle tidligere civilisationer. Ingen andre civilisationer har kunnet opnå en eksponentiel vækstrate, der fordobler det materielle forbrug på 30 år, og indarbejdet en sådan vækst som et grundvilkår for økonomien, verdensopfattelsen og kunsten.

En civilisation der har præsteret det utrolige - men ikke at holde igen med fråds af den ressource, der er dens grundlag. Det kan blive dens undergang. 